\title{
Model Pertumbuhan Dan Status Sumberdaya Panulirus homarus Di Cilacap, Jawa Tengah
}

\author{
Maulvi Didit Baskoro*, Edi Wibowo Kushartono, Irwani \\ Departemen IImu Kelautan, Fakultas Perikanan dan IImu Kelautan, Universitas Diponegoro \\ Jl. Prof.H.Soedarto S.H, Tembalang,Semarang, Jawa Tengah 50275 Indonesia \\ ${ }^{*}$ Corresponding author, e-mail : maulvi.didit.baskoro@gmail.com
}

\begin{abstract}
ABSTRAK : Lobster pasir (Panulirus homarus) merupakan salah satu jenis lobster yang banyak di temukan di perairan Indonesia. Penelitian ini dilaksanakan pada bulan November 2017 sampai bulan Februari 2018 dengan lokasi pengambilan sampel di Pelabuhan Perikanan Samudra Cilacap (PPSC), di Perairan Cilacap Penelitian ini melihat bagaimana model pertumbuhan, dan status sumberdaya, mulai dari Von Bertalanffy, CPUE dan MSY. Estimasi parameter pertumbuhan lobster pasir (Panulirus homarus) dihitung dengan aplikasi Fisat II. Didapatkan hasil model pertumbuhan lobster pasir $\left(L_{\infty}=93.66 \mathrm{~cm}, \mathrm{~K}=0.780\right.$ dan $\mathrm{t}_{0}-1.0950 \mathrm{~mm}$ ). Hasil CPUE didapatkan persamaan, nilai linier sebesar $y=-0.0002+0.0965 x$, nilai $R^{2=} 0,09443$ untuk data lima tahun ke belakang terhitung dari 2012 sampai 2016 dalam upaya penangkapan (Panulirus sp.). Analisa Maximum sustainable yield (MSY) di lakukan untuk mengetahui besarnya potensi lestari Panulirus sp. dengan registrasi linier $y-0.0002 x+0.965$. Pendugaan MSY dan upaya penangkapan $\mathrm{F}_{\text {optimum }}$ diperoleh dengan 2412 trip dan nilai MSY 1164.031. Produksi Panulirus $s p$. di tahun 2016 - 2017 di Perairan Cilacap mengalami kenaikan, pada tahun 2016 terjadi kenaikan di bulan Februari, Maret, April dan Desember. Sedangakan pada tahun 2017 terjadi kenaikan di bulan Maret dan Oktober. Kenaikan ini dikarenakan musim lobster berada di bulan Oktober hingga Februari. Perubahan iklim dan penangkapan yang melebihi batas akan berpengaruh terhadap ukuran dan stok Panulirus sp. di alam.
\end{abstract}

Kata kunci : Panulirus homarus; CPUE; MSY; Von Bertalanffy; PPSC

\section{Model of Growth and Resource Status of Panulirus homarus in Cilacap, Central Java}

ABSTRACT : The Spiny lobster (Panulirus homarus) is one species of lobster that is widely found in Indonesian. This research was conducted on November 2017 until February 2018 the sample locations at the Cilacap (PPSC), which observed the growth of models, and the status of resources, regretion Von Bertalanffy Growth function CPUE and MSY. The estimated growth parameters of sand lobster (Panulirus homarus) were calculated using Fisat II application. The results of the spiny lobster growth model were obtained $(L \infty=93.66 \mathrm{~cm}, K=0.780$ and $0-1.0950$ $\mathrm{mm}$ ). The CPUE results were obtained equations, linear values of $y=-0.0002+0.0965 x$ for five years data from 2012 to 2016 . The Maximum Sustainable Yield (MSY) analysis was carried out to determine the magnitude of the sustainable potential of Panulirus sp. within linear $y-0.0002 x+$ 0.965 . The MSY values 1164,031 estimation and ( $\left.F_{\text {optimum }}\right)$ fishing effort were 2.412 trips and MSY values 1164,031. The production of Panulirus sp. start from 2016 to 2017 in the Cilacap has increased, the fact in 2016 there was an increase on February, March, April and December, while in 2017 there was an increase on March and October. So that the increase due to the lobster season being in October to February. In addition, climate alteration and capture exceed the effect of size and stock of Panulirus sp.

Keywords :Panulirus homarus; CPUE; MSY; Von Bertalanffy; PPSC

\section{PENDAHULUAN}

Perairan Indonesia seluas $1.097 .000 \mathrm{~km} 2$ dari luas tersebut $6.782,48 \mathrm{~km} 2$ diantaranya merupakan habitat lobster (Kanna, 2006). Potensi lobster di perairan Indonesia sebesar 4.800 ton dengan tingkat pemanfaatan pada tahun 1997 sebesar $46 \%$ dan potensi yang cukup tinggi di 
Perairan Samudra Indonesia sebesar 1.600 ton dengan pemanfaatan 45\% (Masithoh, 2014). Indonesia juga merupakan wilayah kepulauan terbesar di dunia, yang menyimpan kekayaan sumberdaya laut yang terbesar pula. Salah satunya adalah sumberdaya lobster yang belum diekplorasi secara optimal.

Lobster pasir (Panulirus homarus) merupakan salah satu jenis lobster yang banyak di temukan di perairan Indonesia, khususnya di perairan Samudera Hindia. Lobster ini di golongkan dalam kelompok lobster berduri (spiny lobster) yang di Indonesia di kenal dengan nama udang karang atau udang barong kerena pada umumnya banyak di temukan di perairan karang. Udang karang atau lobster yang paling banyak di temukan di perairan Indonesia termasuk dalam family Palimuridae dan genera Panulirus (Kembaren et al., 2015).

Larangan penangkapan lobster dengan ukuran panjang karapas kurang dari $8 \mathrm{~cm}$ kemungkinan dapat menjadi hambatan perkembangan perikanan lobster sehingga perlu disiasati dengan cara lain seperti dengan pembesaran dan pembenihan lobster. Salah satu diantaranya adalah belum berkembangnya teknik pematangan ovary (manturasi) induk betina yang menjadi kunci awal tahapan dalam pembenihan krustasea (Firmansyah, 2017).

Salah satu basis Kelautan Perikanan tangkap di pantai Provinsi Jawa Tengah adalah Pelabuhan Perikanan Samudera Cilacap (PPSC) PPSC sebagai salah satu tempat untuk mendapatkan hasil perikanan di Cilacap benar-benar di tuntut fungsinya dalam penanganan hasil tangkapan sekaligus pendistribusi. Nelayan lobster di Cilacap melakukan usaha penangkapan berdasarkan musim dan umumnya nelayan lobster memiliki lebih dari satu alat tangkap, akan tetapi yang paling sering di gunakan adalah jaring insang (gillnet). Menurut Subani dan Barus (1989) dalam Mahdiana dan Laurensia, (2010), Gillnet adalah suatu alat tangkap yang terbentuk empat persegi panjang yang di lengkapi dengan pelampung, bemberat dan tali ris atas dan bawah.

Di alam, pakan yang paling di sukai lobster adalah berbagai jenis kepiting, moluska dan ikan. Jika persediaan pakan tidak memadai, lobster akan memangsa sesamanya inilah yang di sebut sebagai sifat kanibalisme. Peristiwa ini terjadi terutama jika ada lobster yang sedang lemah (sedang berganti kulit) atau pakan yang di berikan kurang tepat baik jenis, jumlah, frekuensi maupun waktu pemberian (Kanna, 2006).

Lobster pasir dapat digolongkan sebagai hewan yang merawat dan memelihara keturunannya walaupun sifatnya hanya sementara. Lobster betina yang sedang bertelur melindungi telurnya dengan cara meletakkan atau menempelkan butir-butir telurnya di bagian bawah badan (abdomen) sampai telur tersebut dibuahi dan menetas menjadi larva. Menjelang akhir priode pengeluaran telur dan setelah dibuahi, lobster akan bergerak menjauhi pantai dan menuju ke perairan karang yang lebih dalam untuk penetasan (Subani 1993 dalam Utami, 1999).

Lobster merupakan pemangsa organisme dasar yang sangat bergantung pada kondisi fauna dasar. Lobster keluar dari tempat tinggalnya untuk mencari makanan. Jenis yang hidup di perairan dangkal akan menuju terumbu karang atau paparan terumbu, sedangkan jenis yang hidup agak dalam akan berkeliaran di sekitar habitatnya. Makanan yang digemari adalah Molusca, Gastropoda (keong, dan kerang) dan Echinodermata (bulu babi, bintang laut, teripang dan lili laut) dan makanan lainnya adalah ikan (Moosa dan Aswandi 1984).

Menurut Santosa (2010), Model Von Bertalanffy digunakan dalam bidang pencarian parameter pertumbuhan ikan. Factor yang paling utama dalam pertumbuhan ikan adalah koefisien pertumbuhan. Dimana koefisien pertumbuhan dapat berupa koefisien konstanta dan koefisien variasi. Sehingga untuk memahami model tersebut, maka diperlukan analisis persamaan Model Von Bertalanffy dengan koefisien bervariasi yaitu dengan mencari solusi persamaannya, sehingga dapat mengetahui perilaku dari kurva pertumbuhan model Von Bertalanffy dengan koefisien konstanta dan bervariasi. Penelitian tahap ini penting dilakukan untuk mengetahui dinamika populasi ikan secara lebih mendetail.

Menurut Sadhori, (1985), Gill net merupakan alat tangkap yang di samping di suatu perairan dan dibiarkan menetap. Dalam hal ini terkadang jaring diberi atau dikaitkan pada suatu tempat yang tetap, dan pada pengoperasiannya jaring insang memerlukan syarat dasar perairan yang tidak berkarang. Gill net adalah jaring yang berbentuk empat persegi panjang dimana di dalam air kedudukannya menghadang pergerakan ikan dan menjerat jaring insang atau membelit badan (Direktorat Jendral Perikanan, 1991). Jenis ikan demersal yang umumnya tertangkap pada jaring insang yang di pasang dekat permukaan laut seperti, udang, lobster, kepiting dan lain-lain. Jaring 
insang yang digunakan nelayan di Perairan Cilacap kebanyakan menggunakan alat tangkap jaring insang permukaan (Surface gill net). Nelayan lobster banyak mengunakan jaring insang permukaan karena harga nya terjangkau dan dapat di beli di warung-warung terdekat, tetapi belum dengan pelampung dan pemberatnya

Tujuan Penelitian untuk mengetahui Von Bertalanffy lonster pasir (Panulirus homarus), mengetahui trend CPUE dan MSY (Panulirus sp.) pada priode waktu 2012-2016. Serta tingkat pemanfaatan (Panulirus sp.) memperoleh informasi mengenai komposisi kimia dari gonad bulu babi berupa kandungan protein, asam amino dan asam lemak gonad bulu babi Arbacia lixula dan Colobocentrotus atratus yang berasal dari Perairan Cilacap, di Pelabuhan Perikanan Cilacap (PPSC), Cilacap, Jawa Tengah.

\section{MATERI DAN METODE}

Pengukuran panjang karapas menggunakan metode berdasarkan pada Sparred dan Venema (1998), yang menyatakan, ukuran yang paling akurat untuk udang dan udang karang adalah "panjang karapas". Panjang karapas diukur mulai dari ujung tandung (dekat mata) hingga batas antara karapas dan abdomen menggunakan jangka sorong (Bakhtiar et al.,2013).

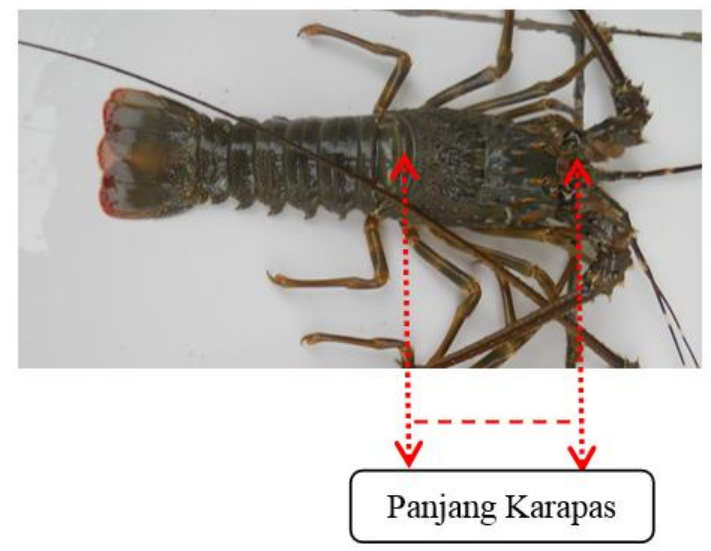

Gambar 1. Panjang Karapas (Sparre, dan Venema,1998)

\section{Model Pertumbuhan Von Bertalanffy}

Data panjang karapas yang diperoleh setiap bulan, kemudian diolah menjadi frekuensi panjang menurut kelas ukuran dengan interval $7.1 \mathrm{~mm}$. Sehingga didapatkan distribusi kelas ukuran panjang karapas sebanyak 11 kelas, pengolahan data model pertumbuhan dibantu dengan menggunkan Program Fisat II. Model Pertumbuhan yang digunakan dalam bentuk : $L t=L_{\infty}\left(1-\mathrm{e}^{-}\right.$ $\mathrm{K}(\mathrm{t}-\mathrm{t}))$. Keterangan : $\mathrm{Lt}=$ panjang biota laut pada waktu $\mathrm{t}(\mathrm{cm}) ; \mathrm{L} \infty=$ panjang maksimum $(\mathrm{cm}) ; \mathrm{K}$ $=$ koefesien pertumbuhan (per tahun); $\mathrm{t}_{0}=$ umur imajiner lobster pada waktu panjang nol. Nilai $L_{\infty}$ dan $\mathrm{K}$ didapatkan dari hasil perhitungan yang telah diolah dengan menggunakan metode ELEFAN 1 yang terdapat dalam sebuah program aplikasi FISAT II, sedangkan untuk mencari nilai $t_{0}$ dapat menggunakan rumus empiris Pauly (Pauly, 1984), yaitu :

$$
\begin{aligned}
\log \left(-t_{0}\right)= & -0,3942-0,10791 \\
& (\log L \infty)-1,9715(\log K)
\end{aligned}
$$

Seluruh nilai yang telah didapatkan untuk $L \infty, K$, dan $t_{0}$ dimasukkan kedalam rumus Von Bertalanffy sehingga didapatkan persamaan serta grafik pertumbuhan. Hal ini dilakukan untuk mengetahui pertumbuhan panjang biota laut hingga mencapai panjang asimtotiknya.

\section{Hasil Tangkapan Per-Upaya Cath Per-Unit of Effort (CPUE)}

Data yang digunakan untuk menghitung CPUE adalah data Sekunder, data diambil dari buku tahunan statistik PPSC dari Priode 2012 - 2016. Hasil Perhitungan ini menghitung penangkapan 
keseluruhan Panulirus sp. di perairan Cilacap. Menurut Noija et al, (2014), untuk menentukan CPUE digunakan rumus :

$$
\text { CPUE }_{\mathrm{t}}=\frac{\text { Catch }_{\mathrm{t}}}{\text { Effort }_{\mathrm{t}}}
$$

Keterangan : CPUEt = hasil tangkapan per upaya penangkapan pada tahun $\mathrm{ke}-\mathrm{t}(\mathrm{kg} / \mathrm{trip})$; Catcht = hasil tangkapan pada tahun $\mathrm{ke}-\mathrm{t}(\mathrm{kg})$; Effortt = upaya penangkapan pada tahun $\mathrm{ke}-\mathrm{t}$ (trip). Menentukan laju penangkapan (CPUE) di peroleh dari rata-rata nilai priode waktu yang panjang. Ini terjadi jika data tersebut dikumpulkan dari hasil tangkap, dimana datanya disajikan secara kuartalan atau tahunan (Sparre \& Venema,1999).

\section{Hasil Lestari Penangkapan Panulirus sp. Maximum Sustainable Yield (MSY)}

Metode perhitungan selanjutnya yaitu mengitung Maximum Sustainable Yield (MSY) lobster pasir, menggunakan data Skunder berupa data Statistik dari PPSC pada tahun 2012 - 2016 untuk menangkapan keseluruhan Panulirus $s p$. di Perairan Cilacap, serta menggunakan pendekatan model Schaefer. Langkah-langkah yang di ambil adalah sebagai berikut :(1) Data produksi satuan bobot (ton) dan upaya penangkapan (effort) dalam satuan trip, time series berdasarkan jenis alat tangkap, (2) Menghitung CPUE.

$$
\mathrm{F}_{\mathrm{opt}}=\frac{a}{2 b}
$$

Dengan menggunakan analisis regresi sederhana dari data times series yang ada, dapat dihitung nilai intersep (a) dan slope (b) sehingga dapat diestimasi hasil tangkapan maksimum dan upaya optimal dari kedua model. (Sparre \& Venema,1999)

Keterangan $: \mathrm{a}=$ Hasil Intersep; $\mathrm{b}=$ Hasil Slope

$$
M S Y:=\frac{a^{2}}{4 b}
$$

Hasil tingkat pemanfaatan dilakukan perhitungan dengan nilai MSY untuk mengetahui kapasitas penangkapan melalui hasil tangkapan, dengan rumus :

$$
\frac{x}{y} \times 100 \%
$$

Keterangan $: \mathrm{x}=$ Nilai hasil produksi $\mathrm{y}=$ Nilai MSY

\section{Penentuan Lokasi Penelitian dan Penangkapan Sampel Lobster Pasir}

Penangkapan lobster pasir banyak di lakukan di sepanjang ceger beton di perairan Cilacap dekat Pelabuhan Perikanan Samudera Cilacap (PPSC). Pengambilan Lobster Pasir banyak dilakukan di Perairan Cilacap yang masih berada dalam kawasan Pelabuhan Perikanan Samudera Cilacap (PPSC), penangkapan lobster menggunakan jaring insang yang Mesh size 4 inci dengan tinggi 1,5 meter dan panjang 4 meter. Sample lobster di ambil sebanyak 1 kali trip dalam satu hari. Pengambilan sampel lobster di lakukan jam

\section{HASIL DAN PEMBAHASAN}

Hasil dari pendugaan data lobster, berupa histrogram dengan memasukkan file dengan format .Ifq (grouped frequncies) yang akan digunakan kemudian memasukkan nilai $L^{\infty}, \mathrm{K}$, dan $\mathrm{t}_{0}$ yang akan dihitung oleh program FISAT II seperti ini : Estimasi parameter pertumbuhan di hitung menggunakan program FISAT II pada Gambar 1. Program FISAT II akan menampilkan persentase rekruitmen selama penelitian. Hasil dari pendugaan menggunakan aplikasi Fisat II di dapatkan $L \infty$ $=93.66, \mathrm{~K}=0.780$. Panjang maksimum karapas sebesar $\mathrm{L}^{\infty}=93.66 \mathrm{~mm}$, dan koefesien/ laju pertumbuhan lobster pasir $\mathrm{K}=0.780 /$ tahun. 


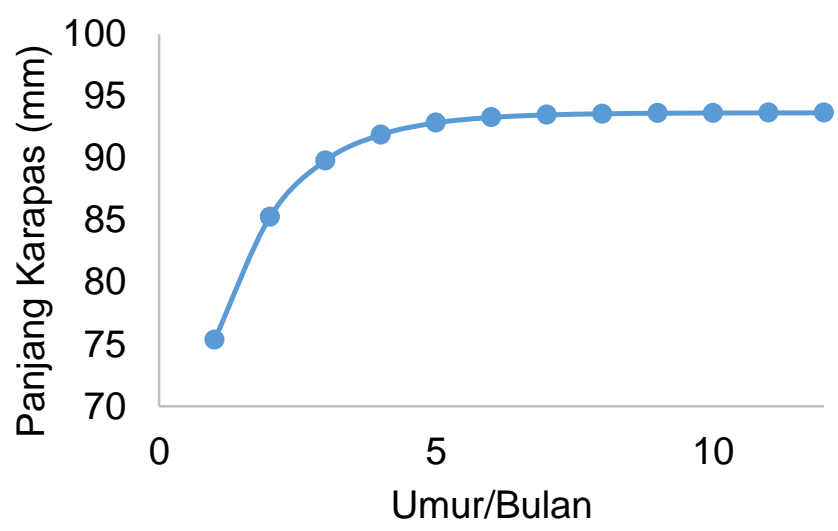

Gambar 1. Penyebaran frekuensi panjang karapas lobster dari $18 \mathrm{~mm}$ sampai $89.2 \mathrm{~mm}$ di Pelabuhan Cilacap



Gambar 2. Kurva Pertumbuhan karapas lobster pasir (Panulirus homarus) di pelabuhan Cilacap

\section{Pertumbuhan Lobster Pasir}

Jumlah lobster pasir (Panulirus homarus) yang diukur selama penelitian setiap per-satu bulan sebanyak 150 ekor, dan jumlah per-emapat bulan sebanyak 600 ekor. Lobster pasir yang diamati memiliki panjang minimum karapas $18.0 \mathrm{~mm}$, dan maximum $89.2 \mathrm{~mm}$. Berdasarkan model Von Bertalanffy di dapat model pertumbuhan 93.66 ( $\left.1-2.71828^{-0.78(t-1.09502)}\right)$. Model pertumbuhan dilakukan tanpa membedakan jenis kelamin jantan ataupun betina. Laju pertumbuhan (K) sebesar $0.74 \mathrm{~mm} /$ per-tahun dan panjang karapas sebesar $93.4 \mathrm{~mm}$.

\section{Upaya Penangkapan dan Potensi Lestari Panulirus sp.}

Nilai Catch per unit effort (CPUE) menghasilkan persamaan linier y $=-0.0002+0.965 \mathrm{x}$, dimana pada tahun 2012-2016 di Pelabuhan Cilacap berfluktuasi dimana pada tahun 2012-2014 terjadi penurunan, dan 2015-2016 terus mengalami penurunan, yang mengakibatkan grafik trendline CPUE menunjukkan line yang terus menurun.

Analisa Maxium sustainable yield (MSY) dilakukan untuk mengetahui besarnya potensi lestari lobster di Pelabuhan Cilacap. Hasil perhitungan regresi linier menunjukkan bahwa y $=$ 0.965-0.0002 x. Pendugaan potensi dapat diteruskan karena nilai slope tersebut bertanda negative dimana nilai tersebut sebagai syarat untuk menentukan MSY (Gambar 5).

\section{Produksi Panulirus sp. Pertahun 2016-2017 di Perairan Cilacap}

Statistik data diambil dari Pelabuhan Penikanan Samudera Cilacap (PPSC) dari tahun 2016 sampai 2017. Data diambil dari jumlah perbulan setiap tahun, yang menunjukkan nilai tingkat pemanfaatan sumberdaya lobster pasir (Panulirus homarus) dalam kurun 12 bulan di 2016, mengalami kenaikan di bulan Januari, Februari, dan Maret, sebanyak 2\%. Bulan April sampai 
Desember mengalami penurunan yang sangat drastis. Tahun 2017 jumlah lobster mengalami penururan pesat tetapi tidak untuk di bulan Februari yang mengalami kenaikan sebanyak 3\% dan September sebanyak $1,3 \%$.

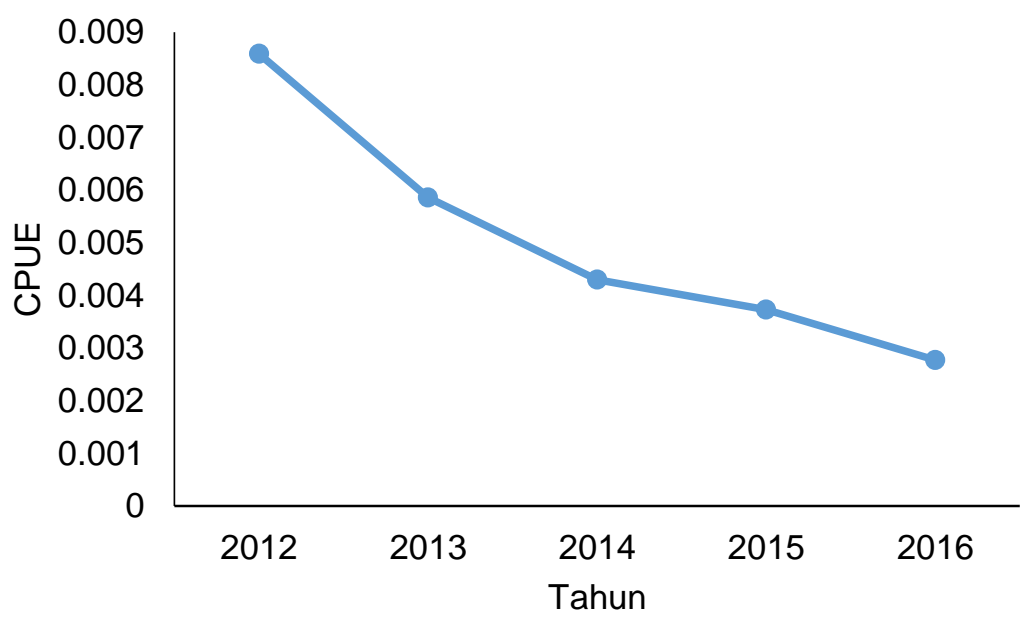

Gambar 3. Fluktuasi CPUE (Catch per unit effort) Panulirus sp. Periode tahun $2012-2016$.

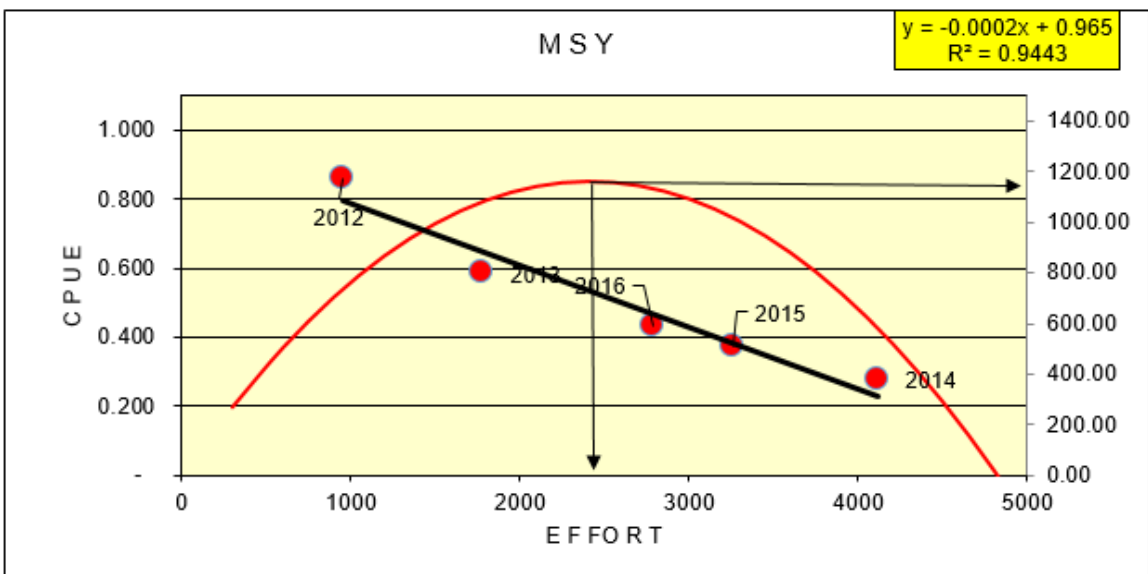

Gambar 4. Grafik MSY Perairan Cilacap Tahun 2012-2016
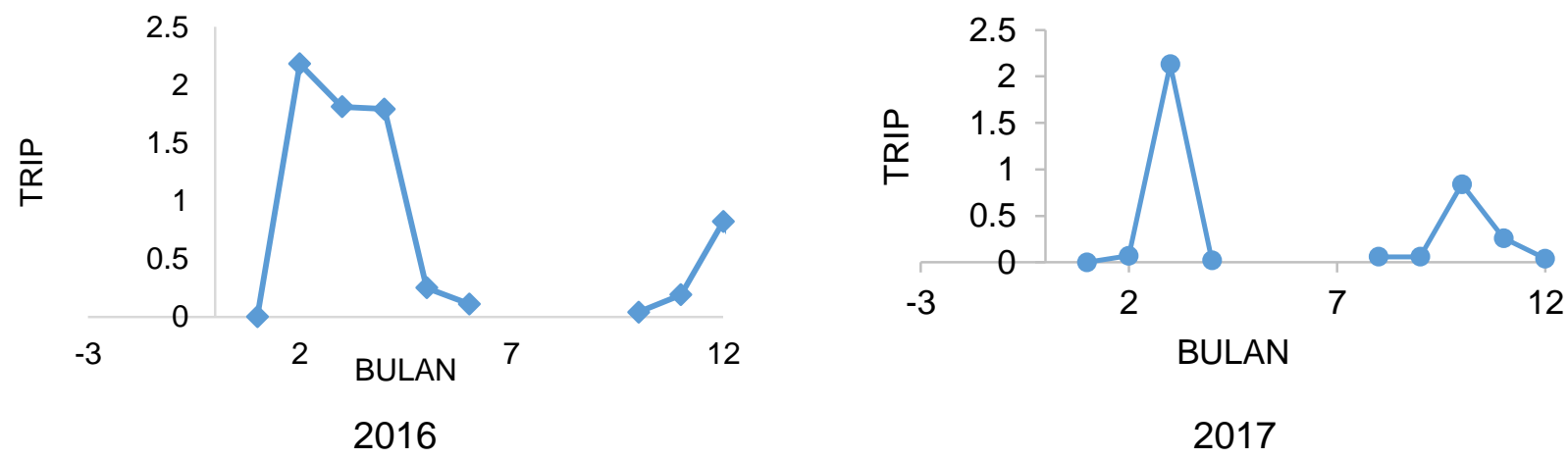

Gambar 5. Persentase penangkapan lobster pertahun 
Hasil analisa perhitungan lobster pasir di dapatkan 11 kelas, 11 kelas ini di dapatkan kerena perhitungan sudah di lakukan dengan berbagai aspek dan dilakukan dengan berbagai macam kelas percobaan. Data yang telah didapatkan menunjukkan bahwa lobster pasir mengalami pertumbuhan di ukuran karapas $18-25.1 \mathrm{~mm}, 25.2-32.3 \mathrm{~mm}, 32.4-39.5 \mathrm{~mm}$. Hal ini menunjukkan bahwa lobster mengalami pertumbuhan berkelanjutan, sesuai dengan pendugaan aplikasi FISAT II.

Estimasi parameter pertumbuhan di hitung dengan aplikasi Fisat II. Didapatkan hasil model

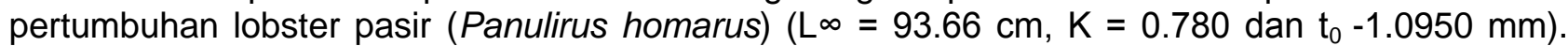
Nilai $\mathrm{K}$ dan $\mathrm{t}_{0}$ dalam penelitian ini lebih besar dari pada (Bakhtiar et al., 2013), yakni $(\mathrm{K}=0.31$ dan $\left.t_{0}-0.37 \mathrm{~mm}\right)$, sedangkan nilai $L \infty$ lebih kecil $\left(L_{\infty}=110 \mathrm{~cm}\right)$. Hal ini disebabkan karena perbedaan kondisi lingkungan, tekanan penangkapan dan waktu yang berbeda saat penangkapan di masingmasing lokasi (Kambaren et al, 2015)

Hasil pendugaan parameter pertumbuhan pada persamaan Von Bertalanffy, dengan menggunakan alat bantu softwere FISAT II dan rumus (Pauly, 1984) untuk menduga $t_{0}$ dan diperoleh hasil nilai K sebesar 0.780. Penelitian yang pernah dilakukan oleh (Bakhtiar et al., 2013) di perairan Cilacap dapatkan nilai $\mathrm{K}$ sebesar 0.31, Perairan Aceh Barat mendapatkan nilai $\mathrm{K}$ sebesar 0.39 yang diteliti oleh (Kembaren et al., 2015)

Hasil penelitian P. homarus yang di lakukan oleh (Bakhtiar et al., 2013) di perairan Cilacap didapatkan nilai panjang total asimtotik $110 \mathrm{~mm}$, dengan nilai $\mathrm{K}$ sebesar 0.31 . Penelitian mengenai Panulirus homarus juga dilakukan oleh (Kembaren et al., 2015) di perairan Aceh Barat yang mempunyai nilai asimtotik $119,5 \mathrm{~mm}$ dan nilai $\mathrm{K}$ sebesar 0.39 . Berdasarkan penelitian di atas antara Perairan Cilacap dan Aceh Barat mempunyai perbandingan nilai $\mathrm{K}$ yang sama, tetapi di Perairan Cilacap PPNC memiliki nilai $\mathrm{K}$ yang lebih tinggi di bandingkan dengan penelitian Bakhtiar et al., (2013) dan Kembaren et al., (2015). Perbedaan nilai pertumbuhan ini kemungkinan di sebabkan oleh perbedaan ukuran sample yang di analisis, priode pengambilan sample, kelimpahan makanan dan kondisi lingkungan.

CPUE dan MSY menentukan grafik penangkapan setiap tahunnya. Berdasarkan analisa data yang telah diambil, penelitian selama empat bulan, dan data penangkapan total lobster pasir selama lima tahun kebelakang, terhitung dari 2012 - 2016, Berdasarkan hasil CPUE didapatkan persamaan, nilai linier sebesar $y=-0.0002+0.0965 x$, yang menyatakan bahwa nilai dari 0,0965 mengalami penangkapan yang berlebih, dan stok lobster yang tersedia dialam sebanyak 0.0965 ton/trip. 0.0002 menyatakan hubungan negative anarata effort dan produksi bahwa setiap pengurangan 1 trip effort akan menyebabkan CPUE naik sebesar 0.0002 ton/trip, begitu pula dengan sebaliknya. Koefisien determinasi (R2) sebesar 0.9443 atau $94.43 \%$ yang menyatakan naik turunnya CPUE sebesar $94.43 \%$, serta dipengaruhi oleh nilai effort dan $5.57 \%$ di pengaruhi oleh faktor lain.

Dapat disimpulkan analisis CPUE diperoleh rata-rata nilai CPUE di PPSC Perairan Cilacap tahun 2012 sampai dengan 20160.505163 ton/trip. CPUE terus mengalami penurunan dan mengindikasikan di perairan tersebut terjadi overfishing. Berdasarkan hasil perhitungan CPUE dipatkan effort mempengaruhi jumlah tinggi rendahnya nilai CPUE dari penangkapan lobster. Hal ini sesuai pernyataan Riswato (2012) bahwa ciri-ciri suatu perikanan tangkap dimana lokasi penangkapan cenderung lebih jauh, produktivitas/laju tangkap (CPUE) cenderung menurun dan biaya penangkapan terus meningkat.

Pendugaan nilai MSY sendiri menunjukkan nilai linier $\mathrm{y}=0.965-0.0002 \mathrm{x}$. Berdasarkan nilai MSY (Gambar 4), maka dapat disimpulkan pada tahun 2012 -2016 mendapatkan rata-rata jumlah trip 2.582 trip/tahun dan hasil tangkap lobster 1.085 ton/tahun. Produksi lobster di PPSC di Perairan Cilacap di tahun 2012 sampai 2016 berada di bawah batas MSY, dimana hasil tangkapan belum melibihi potensi lestari. Dari data yang didapatkan dapat di simpulkan bahwa pada tahun 2012 penangkapan yang telah dilakukan telah melebihi upaya penangkapan optimum. Hal ini didukung oleh Bakhtiar et al. (2013) yang menyatakan pengelolaaan penangkapan tidak melihat besar kecilnya lobster hasil tangkapan dapat berpotensi terhadap overfishing disuatu perairan.

Grafik lobster pertahun 2016-2017 menunjukkan bahwa, hasil tangkapan lobster mengalami kenaikan di beberapa bulan. Jika dikaitkan kenaikan ini terjadi dikarenakan musim lobster lebih ke bulan Oktober hingga Februari. Menurut penelitian (Damora, 2018) di perairan Gunung Kidul Yogyakarta, pada bulan bulan tersebut bertepatan dengan musim hujan. Hubungan antara hasil 
tangkapan lobster awal musim hujan menunjukkan dugaan adanya hubungan sebab akibat. Hal ini terjadi karena pada priode tahun 2016-1017 jumlah trip penangkapan menurun signifikan. Penurunan penangkapan bisa di pengaruhi oleh kondisi di suatu daerah, dan iklim.

Menurut Yao et al., (2010) menyatakan bahwa intensitas hujan di Asia Tenggara meningkat dari kondisi normal dan di kaitkan dengan peningkatan pemanasan muka bumi di Indo-Pasifik. Perubahan iklim dan penangkapan berlebih akan berpengaruh terhadap ukuran dan stok lobster di alam. Menurut Kembaren et al. (2015) Semakin kecil ukuran yang tertangkap maka semakin kecil pula biomassa perekruitnya atau penangkapan, hal ini mengindikasikan bahwa pengelolaan perikanan lobster harus dilakukan dengan prinsip kehati-hatian (precautionary approach).

\section{KESIMPULAN}

Model pertumbuhan panjang karapas lobster pasir (Panulirus homarus) dengan menggunakan perhitungan Von Bertalanffy di PPSC Perairan Cilacap mendapatkan nilai $\mathrm{L} \infty=93.66 \mathrm{~cm}$ dan $\mathrm{K}=$ 0.780. Trend CPUE lobster di PPSC Perairan Cilacap pada tahun 2012 sampai tahun 2016 memiliki persamaan nilai $\mathrm{y}=0.0002 \mathrm{x}-0.965$. Perhitungan Maximum Sustainable Yield (MSY) mendapatkan hasil sebesar 1.164,03, dengan hasil tersebut terlihat bahwa terjadi overfishing pada tahun 2012 dan dapat berdampak pada hasil tangkap lobster.

\section{DAFTAR PUSTAKA}

Bakhtiar, Mukhlish, N., Solichin, A. \& Saputra, S.W. 2013. Pertumbuhan dan Laju Mortalitas Lobster Batu Hijau (Panulirus homarus) di Perairan Cilacap Jawa Tengah. Fakultas Perikanan dan Ilmu Kelautan. Universitas Diponegoro.

Damora A., Wardianto, Y. \& Adrianto, L, 2018. Hasil Tangkapan Per Upaya dan Parameter Populasi Lobster Pasir (Panulirus homarus) di Perairan Gunung Kidul. Marine Fisheries: Journal of Marine Fisheries Technology and Management. 9(1):11-24

Direktorat Jendral Perikanan, 1989. Mengenal Udang Barong (Lobster) Komoditi Ekspor yang Potensial untuk Dikembangkan, Jakarta: Warta Mina.

Firmansyah, 2017. Rangsangan Perkembangan Ovari Lobster Pasir (Panulirus homarus) Pada Wadah Budidaya Melalui Ablasi Mata.

Kanna, I. 2006. Lobster, Yogyakarta: Kanisius.

Kanna, I. 2006. Lobster Penangkapan, Pembenihan, Pembesaran Kanisius, Yogyakarta.

Mahdiana, A. \& Laurensia, S.P., 2011. Status Perikanan Lobster (Panulirus spp.) di Perairan Kabupaten Cilacap. Sains Akuatik 13(2):52-57.

Masithoh, I., Jacob, L.A.U., Jubhar, C.M. \& Suyasatria T., 2014. Aspek Bioekologi Lobster (Panulirus spp.) Sebagai Komoditas Ekonomi Penting. [Prosiding] Universitas Kristen Satya Wacana, Salatiga.

Moosa, M.K. \& Aswandi, I, 1984. Udang karang (Panulirus sp) Dari Perairan Indonesia. Jakarta: royek Studi Potensi Sumber Daya Alam Indonesia,Studi Semberdaya Ikan, Lembaga Oseanologi Nasional, Lembaga Pengetahuan Oseanologi Nasional, Lembaga Pengetahuan Nasional

Riswanto, S., 2012. Status Perikanan Tuna Mata Besar (Thunnus obesus,Lowe 1839) di Perairan Hindia, Selatan Pelabuhan Ratu, Sukabumi. Universitas Diponegoro, Semarang

Sadhori, N.1985. Teknologi Penangkapan Ikan. Penerbit Angkasa, Bandung. 175 hal.

Sentosa, A. 2010. Kajian Dinamika Populasi Ikan Waader Pari (Robosta iateristriata) di Sungai Ngancah, Kabupaten Kulon Progo. Seminal Nasional Tahunan VII Hasil Perikanan dan Kelautan. Yogyakarta: Lembaga Penelitian UGM.

Sparre, P..\& Venema, S.C., 1998. Introduksi Pengkajian Stok Ikan Tropis. Organisasi Pangan dan Pertanian, Jakarta. HIm.13

Subani, W. Suman, A. \& Prahoro. 1993. Beberapa Parameter biologi udang panning (Panulirus homarus) di Perairan Pangandaran Jawa Barat. Jurnal Penelitian Perikanan Laut 85:1021

Utami, D.D.Y, 1999. Analisis Sumberdaya dan Tingkat Pemanfaatan Lobster (Panulirus sp) yang Didaratkan di Pengandaraan, Ciamis, Jawa Barat. Program Studi Pemanfaatan 
Sumberdaya Perikanan, Fakultas Perikanan dan IImu Kelautan, Institut Pertanian Bogor, Bogor $60 \mathrm{hlm}$.

Yao, C., Qian, W., Yang, S. \& Lin, Z. 2010. Regional Features of Precipitation Over Asia and Summer Extreme Precipitation Over South east Asia and Their Associations with Atmospheric-Oceanic Conditions. Meteorology and Atmospheric Physics. 106:57-73. 